\title{
Transgenic rice evaluated for risks to marketability
}

by Dustin R. Mulvaney, Timothy J. Krupnik and Kaden B. Koffler

\section{The California Rice Certification Act} mandates specific planting and handling protocols for rice varieties, including transgenic rice, that may pose economic risks to California rice growers. Based on a literature review and extensive interviews, we describe this policy's evolution as a system for identity preservation and explain how it shapes the potential commercialization of transgenic rice. Several studies suggest that transgenic rice would be profitable for California growers, but the challenges in assuring $100 \%$ identity preservation - especially when access to export markets is at risk - means that the commercial approval of transgenic rice in California is unlikely until there is widespread market acceptance and growers are assured of no sales interruptions.

$\mathrm{T}$ en years after the first regulatory approval of genetically engineered, or transgenic, rice in the United States, none is grown commercially. This contrasts with high adoption rates for transgenic soy $(93 \%)$, corn $(70 \%)$ and cotton $(78 \%)$ (ERS 2010). The trend is similar globally: the transgenic rice closest to market is 'Xianyou 63', an insect-resistant (Bt, Bacillus thuringiensis) variety that was approved by China in 2009 and is expected to be available by 2012 (James 2009). Some experts contend that commercialization in China will usher in a wave of transgenic rice approvals and adoption (Serapio 2010), which could have implications for the California rice industry.

We review the economic benefits and risks from transgenic rice and explain how market concerns shape California growers' perceptions of transgenic rice. Several studies suggest that transgenic rice would benefit California rice growers - particularly herbicide-tolerant varieties to help manage weeds (Annou et

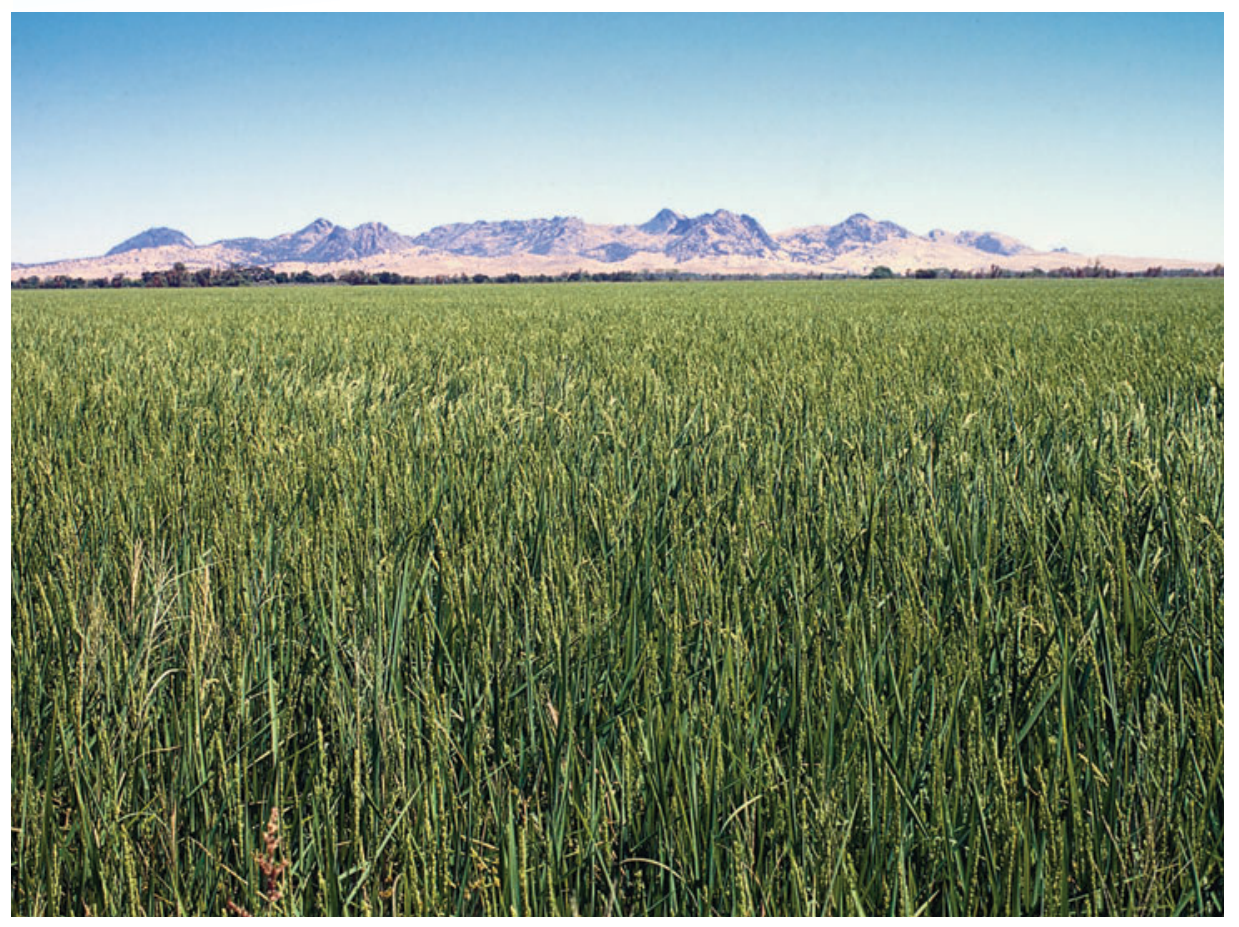

Herbicide-tolerant rice has been developed to help farmers with costly weed problems. Above, Colusa County rice with at least three severe weed species.

al. 2000; Bond et al. 2005). However, transgenic rice also presents economic risks to California rice growers, who rely on exports for half of their sales. Buyers could refuse to purchase stocks contaminated by transgenic rice, impose costly testing requirements or shut down markets permanently.

In 2001, UC Cooperative Extension surveyed 213 California rice growers, and $37 \%$ stated that if herbicide-tolerant rice were available they would not plant it. A subgroup of $78 \%$ suggested that this was due to "market concerns" (UCCE 2001). California growers produce over 1,980 tons (1,800 metric tons) annually valued at over $\$ 200$ million, and close to $\$ 500$ million when government payments are factored in. Many rice growers rely on export markets; as much as $40 \%$ of California rice is sold to Japan annually (Fukuda et al. 2003). These export markets, however, are not entirely secure, and the U.S. Department of Agriculture's Economic Research Service (2001) has described U.S. involvement as "thin, volatile and risky" (see sidebar, page 163).

To manage risks to marketability, the California Rice Certification Act (CRCA) regulates rice with "characteristics of commercial impact," including transgenic rice. The CRCA relies on a risk management scheme called identity preservation (IP), which refers to "production, handling and marketing practices that maintain the integrity and purity of agricultural commodities" (Sundstrom et al. 2002). Many crops - such as cotton, where keeping varieties of different fiber consistently separate is critical to marketability - require identity preservation for quality control. Identity preservation is also used to manage "genetic pollution" risks from transgenic crops (Ellstrand 2006), particularly those not approved for human consumption or used to make pharmaceuticals (Marvier 2007). In these latter cases, identity preservation must be $100 \%$ effective.

To explore the CRCA's evolution and effectiveness, all published accounts were surveyed, including journals, reports, media coverage, industry newsletters and regulatory agency publications.

Forty-eight semistructured interviews

Originally published online only.

http://californiaagriculture.ucanr.org/

landingpage.cfm?article=ca.E.v065n03p161\&fulltext=yes

DOI: 10.3733/ca.E.v065n03p161 
were conducted with key policymakers, scientists, activists and growers working on issues related to transgenic crops and the rice industry. Using snowball sampling methodology, interviewees provided new contacts until additional interviews yielded no new informants, and informants yielded no new pertinent information (Salganik and Heckathorn 2004). Interviews and follow-up conversations were conducted from 2004 to 2010 and included 14 UC and industry scientists, eight rice growers, six rice marketers, six activists and 18 policymakers. This approach captured the range of views expressed by key individuals, firms and public institutions.

\section{Glossary}

Adventitious presence: A low-level, inconsequential presence of unintended genetic materials (e.g., transgenic seed).

Breeder, foundation and certified seed: Crops grown to produce seeds for planting.

Coexistence: The dual production, distribution and marketing of transgenic and nontransgenic varieties, with an emphasis on keeping them separate.

Commingling: The inadvertent mixture of seed or grain products.

Containment: Using spatial, temporal or biological isolation to prevent gene flow by keeping biological materials inside a set boundary.

Gene flow: The movement and exchange of genetic traits or biological organisms from one population to another.

Genetically engineered, genetically modified or transgenic organism: An organism produced by combining DNA from different sources, either from within the organism's genome or from another organism.

Identity preservation (IP): Handling practices to ensure that a product can be traced to its genetic/biological source (seed) and production location (e.g., a specific agricultural field).

Precautionary principle: When the consequences of a proposed action are severe or irreversible, policy should err on the side of caution.

\section{Potential transgenic rice benefits}

Weeds strongly affect yields and profitability in California rice production. Weed management requires multiple herbicide applications, which can be costly. Growers can spend up to $\$ 200$ per acre on herbicides (Bond et al. 2003). One proposed weed control strategy is herbicide-tolerant rice modified to contain genes resistant to broad-spectrum herbicides. Herbicide-tolerant rice allows herbicides to be sprayed shortly after seedlings emerge, when rice-weed competition is highest and the potential for weed-inflicted yield losses is greatest. Reducing weed density and biomass early gives herbicide-tolerant rice seedlings a competitive advantage for solar radiation, nutrients and water.

Herbicide-tolerant rice could simplify weed management because it requires just one herbicide, rather than multiple selective herbicides for specific weed biotypes. One study suggests that herbicide-tolerant rice could decrease herbicide requirements by up to $84 \%$ (Bond et al. 2005). This would reduce costs and provide environmental benefits by promoting alternatives to more toxic herbicides (Ueji and Inao 2001). After accounting for additional costs - including seed technology fees, identity preservation costs, short-term yield reductions and CRCA fees - such research suggests that herbicide-tolerant rice would be profitable for California growers (Bond et al. 2003).

However, important impacts are obscured when costs and benefits are analyzed without considering how the adoption of transgenic rice would affect the marketability of exported rice. These studies assume no change in marketability or prices, and that transgenic herbicide-tolerant rice would be broadly accepted. However, market rejection of exports could have severe economic repercussions, so profitability analyses will ultimately hinge on successfully containing risks.

\section{LibertyLink contamination}

In August 2006, the U.S. Food and Drug Administration announced that Bayer's long-grain LibertyLink transgenic rice (LL601) — not yet approved for human consumption - extensively commingled with long-grain 'Cheniere' rice and foundation seed grown in five southern U.S. states (FDA 2006). Over the ensuing months, major importers of U.S. rice - Japan, South Korea, Taiwan, Mexico, Russia and the European Union (EU) - banned or halted all imports of long-grain rice from the United States (Vermif 2006). The FDA retroactively approved LL601 for human consumption to reassure consumers that it was safe. But by that time, rice futures prices had fallen on the Chicago Board of Trade, and growers had entered into futures contracts at lower prices than anticipated (GAO 2008). University of Arkansas economists later confirmed a large and adverse (but shortlived) price drop (Li et al. 2010).

Another of Bayer's LibertyLink varieties (LL604) was later found in 'Clearfield 131 ' rice seed marketed by a competing seed company, BASF. It was recalled after USDA asked that it not be sold or distributed, costing BASF millions of dollars in seed sales (GAO 2008). These events prompted additional testing requirements in export markets, and significant resources were mobilized to remove LibertyLink rice from the seed supply. An industry executive estimated domestic impacts to growers between $\$ 80$ million to $\$ 100$ million (Cole 2006), while an attorney representing affected growers in a class-action lawsuit against Bayer esti-

\section{The LibertyLink incidents did little to instill confidence that experimental field trials of transgenic crops could always be adequately contained.}

mated damages at $\$ 1$ billion (GAO 2008).

Drawing on USDA data, the U.S. Rice

Federation suggested that rice exports to the European Union fell 68\% from 2005 to 2007 (Cummings 2009). EU importers who deliver U.S. rice to market were also affected, losing an estimated $€ 52$ million to $€ 111$ million in 2006 and 2007 (Brookes 2008). While USDA did not definitively identify the contamination source, a jury awarded a dozen growers a \$48 million judgment against Bayer, which owned the LibertyLink varieties grown in experimental field trials from 1999 to 2001 at a research station in Louisiana. Bayer 
has lost six similar cases so far, and hundreds more are pending (Cronin Fisk and Whittington 2010).

Rice futures prices eventually recovered, as energy costs and commodity speculation drove bidding to record highs in 2008. But LibertyLink was detected in subsequent shipments, preventing marketers from taking advantage of high prices and effectively restricting U.S. ride trade with the European Union (GAO 2008). California rice growers were largely unaffected by the LibertyLink incident, because they primarily grow short- and medium-grain rice (table 1). Only one
TABLE 1. Regulatory status and field-test locations for Bayer's LibertyLink (LL) rice

\begin{tabular}{|c|c|c|c|c|}
\hline Variety & Grain type & Federal regulatory status* & Calif. certification status $†$ & Field-trial locations \\
\hline LL62 & Medium & Approved 1999 & $\begin{array}{l}\text { Approved for greenhouse } \\
\text { trial in } 2008\end{array}$ & La. (2); Puerto Rico (2); Calif. \\
\hline LL06 & Medium & Approved 1999 & Not approved & Calif. (10); Puerto Rico (2) \\
\hline LL601 & Long & Approved 2006‡ & Not approved & $\begin{array}{l}\text { Ark., Miss., Mo., Texas, La., } \\
\text { Puerto Rico }\end{array}$ \\
\hline LL604 & Long & Not approved & Not approved & $\begin{array}{l}\text { Ark., Miss., Mo., Texas, La., } \\
\text { Puerto Rico }\end{array}$ \\
\hline \multicolumn{5}{|c|}{$\begin{array}{l}\text { * Includes Food and Drug Adminstration, Environmental Protection Agency and U.S. Department of Agriculture Animal and Plant Health } \\
\text { Inspection Service. Federal approval does not automatically entail approval at the state level. }\end{array}$} \\
\hline
\end{tabular}

\section{Biosafety or trade barrier? Japan's tenuous trade with California}

\begin{abstract}
Tapan is the California rice industry's largest international customer, purchasing more than $\$ 421$ million in 2009 - over $40 \%$ of the industry's exports (FAS 2010). If tests on imports find transgenic traits, Japan has suggested that it would deny rice shipments. Some observers question whether such policies are about biosafety or if they constitute a barrier to trade.
\end{abstract}

Rice is culturally, religiously and politically significant in Japan. Japan has invoked national food-security policies that promote self-sufficiency and smallholder paddy production (OhnukiTierney 1993); nonetheless, it is a leading food importer, deriving about $40 \%$ of its total calories from imports (Sato 2007). Like California, Japan produces temperate, medium-grain japonica varieties. In Japan, however, per-acre production costs are 10 or more times higher, and consumer prices are two to three times higher than in California (Fukuda et al. 2003). Post-World War II land reforms divided rice-growing areas into holdings of less than 7 acres. In contrast with other food commodities, Japan is self-sufficient in rice production and tends to guard its domestic rice markets against imports.

During the 1994 Uruguay Round of international trade negotiations, Japan yielded to U.S. pressure and agreed to phase out rice import restrictions, reduce government subsidies and annually increase the amount of rice it imported. Japan is required to import more than 680,000 tons of rice per year (Fukuda et al. 2003). About 100,000 tons of this rice is used in food and beverage manufacturing; the rest is directed to government warehouses for eventual re-exportation as foreign food aid (Fukuda et al. 2003). In 2006, Japan announced that

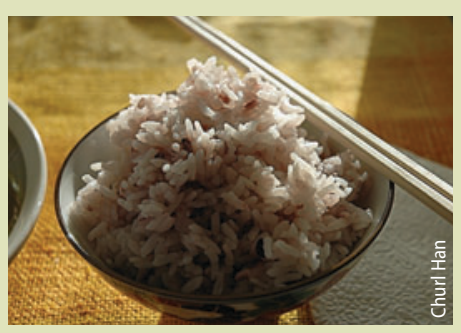
Turkey and South Korea, maintain rice import protocols similar to those of Japan. Both Taiwan and South Korea also have Uruguay Round commitments that are contradictory to the interests of domestic the rice surpluses stored in government warehouses would also be used for biofuels (Annon 2006), and production commenced in 2009 (Takada 2009).

Japan's strict policies on transgenic rice are rooted in both concerns about biosafety and economic protectionism. The Cartagena Protocol on Biosafety part of the United Nations Convention on Biodiversity - allows countries to base decisions about transgenic organisms on the precautionary principle. When risks from biotechnologies are severe and potentially irreversible, nations can implement labeling and other regulatory requirements. Codex Alimentarius, the international standards-setting organization for food safety, has developed guidelines for food derived from biotechnology (i.e., transgenic foods) and suggests labeling as an appropriate approach to risk management (Codex 2003). Both institutions seek to ensure that restrictions on trade are not rooted in protectionism and are informed by the best available information about food safety and environmental consequences.

Unfortunately for California rice growers, other foreign customers that also import japonica rice, such as Taiwan, rice farmers in those countries, and both have asserted strict import restrictions on transgenic rice. Turkey banned transgenic rice altogether. While it is difficult to determine whether protectionism, culture or biosafety are the main forces driving such policies, all play a role in influencing the deployment of transgenic rice.

$$
\begin{aligned}
& \text { - D.R. Mulvaney, T.J. Krupnik, } \\
& \text { K.B. Koffler }
\end{aligned}
$$

\section{References}

Annon A. 2006. Stockpiled import rice to be used in biofuel. Asahi Shimbun. www.asahi.com/english/Heraldasahi/TKY200611140179.html (accessed Feb. 27, 2008).

[Codex] Codex Alimentarius. Foods Derived From Biotechnology. ftp://ftp.fao.org/codex/Publications/Booklets/ Biotech/Biotech_2003e.pdf (accessed Dec. 5, 2010). [FAS] Foreign Agricultural Service. 2010. Global Agricultural Trade System Online. US Department of Agriculture. Wash., DC. www.fas.usda.gov/gats (accessed Dec. 7, 2010).

Fukuda H, Dyck J, Stout J. 2003. Rice Sector Policies in Japan. Electronic Outlook Report. US Department of Agriculture, Economic Research Service. Washington, DC. RCS-0303-01.

Ohnuki-Tierney E. 1993. Rice as Self: Japanese Identities Through Time. Princeton, NJ: Princeton Univ Pr. 184 p. Sato S. 2007. Japan Biotechnology Annual Report. Global Agriculture Information Network Rep JA7040. US Department of Agriculture, Foreign Agricultural Service. Washington, DC.

Takada A. 2009. Japan sake brewer to begin biofuel output from imported rice. Bloomberg News. http:// checkbiotech.org/node/25683 (accessed Nov. 1, 2009). 
importer who resells rice from the affected region lost sales (B. Lundberg, Lundberg Family Farms, personal communication, 2006).

The LibertyLink incidents did little to instill confidence that experimental field trials of transgenic crops could always be adequately contained. Contamination from transgenic rice field trials was involved in 20 of 39 international commingling incidents in 2009 and 2010 (GMO Contamination Register 2010). Since 1996, more than 100 field trials of transgenic rice have been conducted in California (table 2), although to date seasonal testing of California rice seed for transgenic traits has found no contamination (CRC 2010).

\section{Regulating risks}

In 1999, the seed company AgrEvo, which is now owned by Bayer, petitioned to deregulate another LibertyLink variety (LL62). At that time, controversies over transgenic crops were making headlines. Exports of U.S. transgenic soy and corn were refused at European ports (Goldberg 2000), and from 1997 to 2005, U.S. exports of corn to the European Union fell
$\$ 211$ million annually to $\$ 200,000$, while U.S. soy fell from $\$ 2.3$ billion to $\$ 511$ million (Zerbe 2007). A number of other high-profile, unauthorized releases of regulated transgenic crops into the food supply followed (table 3).

California rice growers and industry representatives were aware that the improperly managed introduction of transgenic rice could have economic repercussions, including poor consumer confidence, and lost sales and market access. With the support of a number of nonprofit organizations, the California Rice Commission (CRC), which represents about 1,000 rice growers, pursued a regulatory mechanism to control such risks. By 2000, the California Rice Certification Act (CRCA) was law (see box).

Under the CRCA, the CRC can propose regulations to the California Secretary of Agriculture for rice with characteristics that affect its marketability, including those difficult to identify without specialized testing and those considered expensive or impossible to remove. Though not named explicitly, transgenic rice is clearly regulated by the CRCA. When rice with

TABLE 2. Applications to USDA for transgenic rice trials in California, 1996-2009*

\begin{tabular}{llc}
\hline \hline Trait & Institution & Applications \\
\hline Herbicide tolerance & UC Davis, Louisiana State University, Aventis, Bayer Crop & 61 \\
& Science, Syngentia, AgrEvo and Monsanto & 7 \\
Pharmaceutical & Ventria Biosciences & 7 \\
Salinity tolerance & Arcadia Biosciences & 6 \\
Nitrogen-use efficiency & Arcadia Biosciences & 4 \\
Sterility & Bayer & 8 \\
Yield enhancements & Research for Hire, Monsanto & 10 \\
Bacterial/disease resistance & UC Davis & 6 \\
Altered metabolism/proteins & Aventis & 6 \\
Visual markers & UC Davis & \\
\hline Source: ISB 2009. & & \\
* Organisms with multiple transformations were counted multiple times. Not all applications were approved. &
\end{tabular}

TABLE 3. Unauthorized releases of regulated transgenic crops into the food supply

\begin{tabular}{|c|c|c|c|c|c|}
\hline Year & Product & Crop & Trait & Cause & Detection \\
\hline 2000 & StarLink & Corn & $\begin{array}{l}\text { Insect resistance, } \\
\text { herbicide tolerance }\end{array}$ & $\begin{array}{l}\text { Cross-pollination, } \\
\text { commingling after harvest }\end{array}$ & 3rd-party testing \\
\hline 2002 & Prodigene & Corn & $\begin{array}{l}\text { Pharmaceutical } \\
\text { protein }\end{array}$ & $\begin{array}{l}\text { Cross-pollination, } \\
\text { uncontrolled volunteers }\end{array}$ & USDA inspection \\
\hline 2004 & Syngenta Bt10 & Corn & Insect resistance & Misidentified seed & 3rd-party testing \\
\hline 2006 & LibertyLink 601 & Rice & Herbicide tolerance & Not determined & 3rd-party testing \\
\hline 2006 & LibertyLink 604 & Rice & Herbicide tolerance & Not determined & 3rd-party testing \\
\hline 2008 & Event 32 & Corn & Insect resistance & Under investigation & Developer testing \\
\hline
\end{tabular}

\section{Key provisions of the California Rice Certification Act (AB2622)}

Rice industry partners will work cooperatively to maintain consumer confidence and the acceptance of rice produced and milled in the state.

The task force shall recommend regulations relating to rice identified as having characteristics of commercial impact.

The CRC has the authority to establish terms and conditions for the production and handling of rice to minimize the potential for commingling of various types of rice, and to prevent commingling where reconditioning is infeasible or impossible.

problematic characteristics is identified, the CRC convenes a task force - representing growers, marketers, $\mathrm{UC}$, the California Warehouse Association and the Cooperative Rice Research Foundation to develop identity preservation protocols and keep it out of commodity streams for conventional rice.

Identity preservation requires special planting, handling and auditing procedures along the path from the rice field to customer. Gene flow - the movement and exchange of genetic traits or biological organisms from one population to another - must be contained in rice fields. This requires physical or biological barriers to prevent rice pollen and seed from moving via wind, wildlife or flooding (Lu and Snow 2005). For rice, pollen-mediated gene flow is restricted by short dispersal (Song et al. 2003) and brief viability (Lu and Snow 2005). Seedmediated gene flow can occur over longer distances, because rice seed remains viable for much longer, and dispersal can be assisted by high winds during aerial seeding, floods, wildlife or human error. California's rice fields are habitat to hundreds of millions of waterfowl migrating along the Pacific Flyway, making them potentially important gene-flow vectors. Seed dispersal can be minimized through spatial isolation, prohibitions on aerial seeding, closed-loop water recirculation requirements and wildlife exclusion nets (see box, page 165), although such precautions are likely to significantly 
raise production costs. Monitoring for rice crop volunteers in subsequent seasons and leaving land fallow between transgenic and conventional cultivation can also reduce gene flow. Pollen and seed management are most critical where commercial seed is produced, since the distribution of contaminated seed would have far-reaching impacts. Breeders provide foundation seed to contract growers of certified seed, who in turn produce seed for growers. While breeders already employ practices that limit gene flow, the prospect of incidental transgenic contamination raises the stakes for maintaining purity. This point was underscored in the LibertyLink incidents, where 'Cheniere' and 'Clearfield 131' foundation seed (representing 39\% of the certified seed acreage in Arkansas) were contaminated (Schultz 2006). Growers seeking nontransgenic seed can not use these varieties until the transgenic traits are no longer detected, which can be several years.

Ultimately, the extent to which identity preservation can mitigate risk depends on the enforcement of standards set by buyers. Most identity preservation systems allow for a low-level presence of unintended characteristics, referred to as adventitious presence. Postharvest buyers typically only permit the adventitious presence of traits posing no human health risks. For example, Japan allows up to 5\% of soy imports to contain transgenic soy that has been approved by its food safety regulators. But there is zero tolerance for unapproved crops, which often include experimental crops; with no margin for error, identity preservation is considerably more challenging.

Japan, the largest foreign importer of California rice, maintains some of the world's strictest food safety standards. Incoming shipments of rice are routinely tested for transgenic traits, which if found can result in refusal of the shipment. The LibertyLink incidents suggest that Japan will continue to maintain zero-tolerance policies for transgenic rice and would reject contaminated rice imports.

Many forecasts that determine potential impacts from the adoption of herbicide-tolerant rice base their claims on farm budget analyses that assume market acceptance (Bond et al. 2005). These studies assume modest cost increases for identity preservation but do not incorporate the economic risks associated with contamination incidents. These assumptions are important, because rice contaminated by transgenic traits can cause severe, long-lasting and potentially irreversible impacts on marketability.

The CRCA has drawn attention as a model policy for managing economic risks from transgenic crops (Taylor et al. 2004). While such management is unique, there are precedents for employing identity preservation systems: the cotton industry ensures consistent fiber quality, organic certification tracks crops for labeling, and seed purity is maintained in seed certification and quality control programs (Sundstrom et al. 2002).

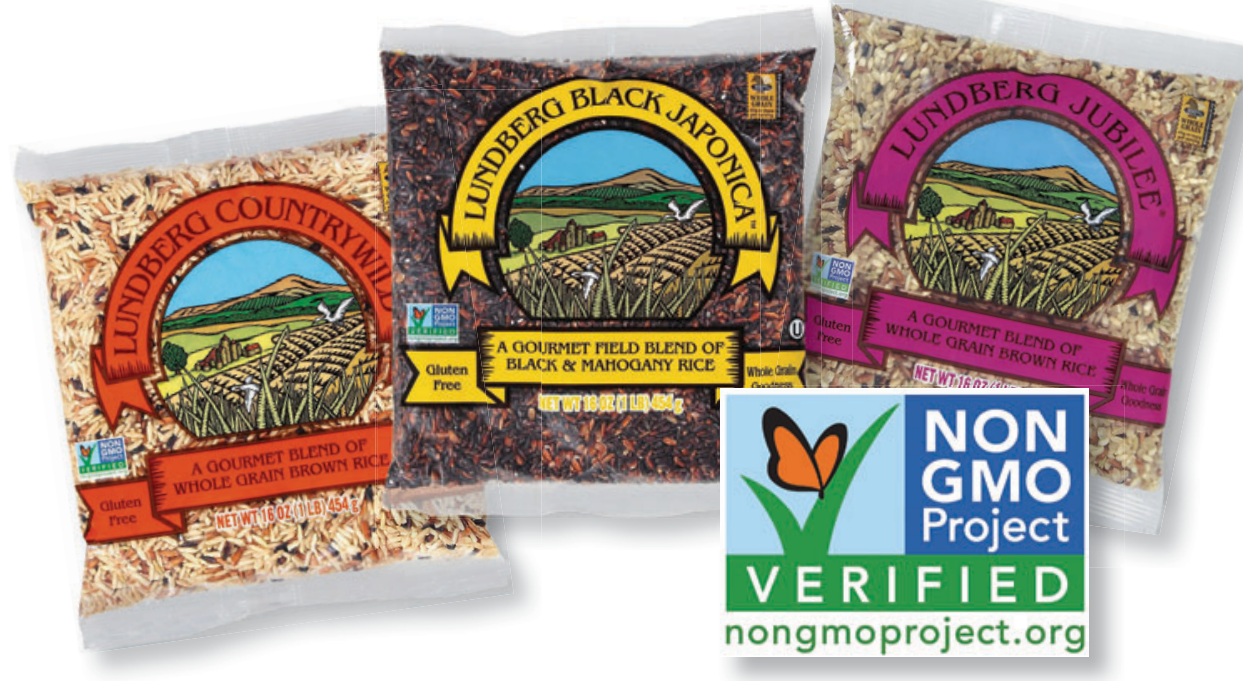

Lundberg Family Farms clearly labels its products as "non-GMO," meaning that they contain no genetically modified organisms. (Lundberg Family Farms rice are Non-GMO Project verified. Lundberg Family Farms does not support the deregulation of "transgenetic" rice.)

\section{Pharmaceutical rice protocols}

The CRCA first applied identity preservation to transgenic rice in late 2003, when Ventria Biosciences sought approval to commercially plant out two rice varieties engineered to produce pharmaceutical compounds that have antimicrobial qualities. The proposed varieties were engineered with recombinant ( $r$-) human proteins, r-lacto-ferrin and r-lysozyme, which were intended for use in the production of iron supplements and antidiarrheal medicines. "Pharm" rice was grown in experimental plots in California from 1999 to 2003 (ISB 2009). When Ventria notified the CRC of its intent to commercialize production, a task force

\section{Containment and identity preservation practices}

\section{Containment}

- Spatial/temporal isolation or buffer zones between transgenic and nontransgenic crop fields.

- Clearly labeled and dedicated equipment for seeding, harvesting, transporting and handling.

- Netting to keep birds and other wildlife from entering fields.

- Screens to keep seed and seedlings from moving into drainage ditches and other waterways.

- Prohibitions against aerial seeding.

- Monitoring for crop volunteers on fields and margins.

- Postharvest tillage to reduce the regrowth of rice from stubble.

- Seed sterility.

\section{Identity preservation}

- Transgenic/nontransgenic labeling on rice bags, silos and trailers.

- Dedicated equipment for drying, hulling, processing and shipping.

- Inspections and documentation demonstrating that shared equipment has been properly cleaned out between processing transgenic and nontransgenic products.

- Clear product custody reports along the distribution path.

- Preventing seed spillage when transferring seed or grain in and out of equipment. 


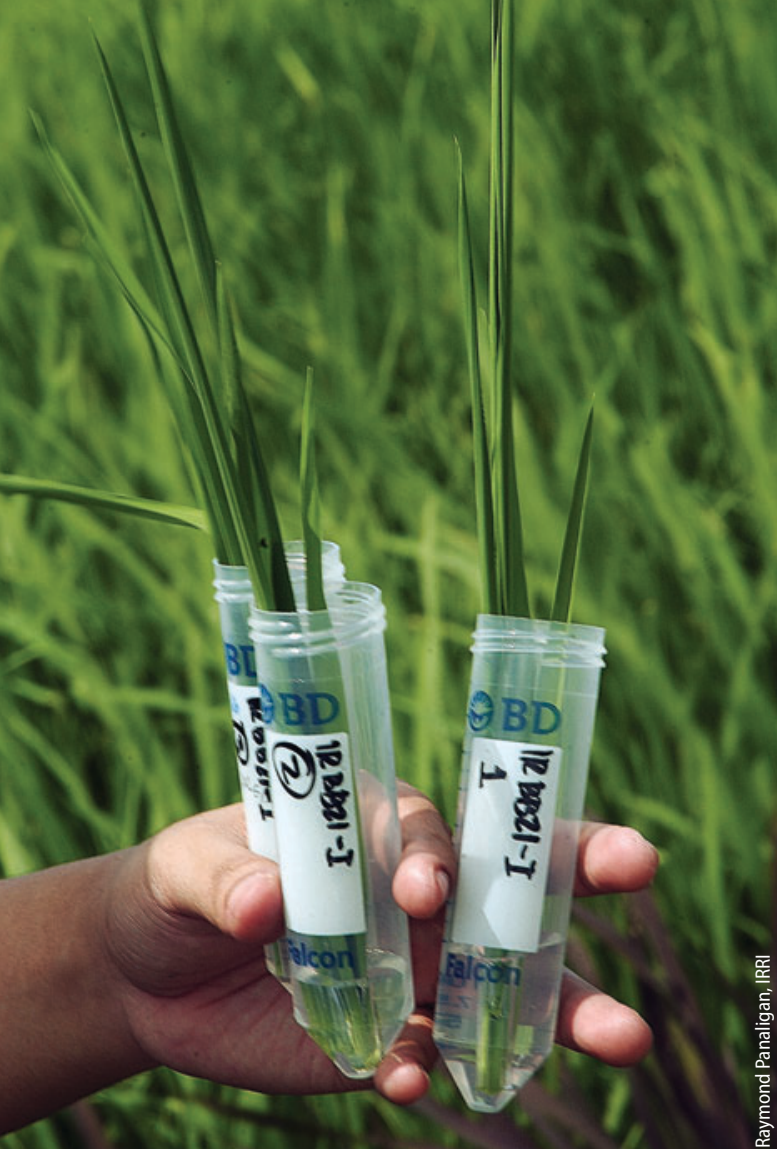

Above, leaf samples of transgenic rice lines that were subjected to DNA extraction in the laboratory.

was convened to develop planting and handling protocols. These protocols were not yet complete when Ventria asked the CRC to permit planting on an emergency basis so they could cultivate during the 2004 growing season (Moschini 2006).

In March 2004, the CRC task force voted six to five to approve Ventria's request, but with several restrictions. Pharm rice was permitted only in counties that were geographically isolated from California's primary rice-growing regions. Aerial seeding was prohibited, and practices to discourage wildlife movement and dedicated equipment were required.

Since these protocols modify the California agriculture code, the Secretary of the California Department of Food and Agriculture (CDFA) can veto decisions by the CRC task force within 10 days. CDFA received a letter from the Japanese Rice Retailers Association that stated, "It is certain that the commercialization of [pharm] rice in the United States will evoke a distrust of U.S. rice as a whole among Japanese consumers, since we think it is practically impossible to guarantee no rice contamination ... If the crop is actually commercialized in the United States, we shall strongly request the Japanese government to take measures not to import any California rice" (Taylor et al. 2004). Such threats were not without precedent: in January 2002, Japan briefly blocked imports of rice bags with leadbased pigments because of food safety concerns (Fukuda 2002).

According to our interviews, concerns about market losses strongly influenced the CDFA decision to veto the planting protocol. The official decision was justified on the grounds that insufficient time was provided for public comment, and that Ventria had not obtained the relevant federal-level permits (Marvier 2007). Ventria subsequently moved operations to Missouri, and Anheuser-Busch said they would refuse to purchase Missouri rice if pharm crops were planted. Ventria next moved to North Carolina, a state without commercial rice production; however, the pharm rice field trials are reportedly taking place near the Tidewater Research Station, where many rice varieties are bred and tested (UCS 2006).

\section{Gaps in CRCA oversight}

Even before the LibertyLink incidents, many of our interviewees expressed concern about experimental field trials for transgenic crops (see box). These trials are the responsibility of the USDA Animal and Plant Health Inspection Service (APHIS), which requires strict containment protocols. Early in CRCA implementation, additional regulation was considered redundant. But in the wake of the LibertyLink incidents, which originated from experimental trials, there were calls for the CRCA to regulate field trials (RPC 2006). The CRC responded, and now experimental field trials require CRCA approval.

Another area of concern was the proximity of experimental field trials to the foundation rice seed supply. The California Rice Experimental Station in Biggs (Butte County) hosts many breeding programs and is where much of the industry's seed originates. Although no transgenic rice field tests have occurred there since 2003, there is no formal policy on future research. Tests of Biggs foundation seed found no transgenic-rice traits from 2007 to 2010 (CRC 2010). Nonetheless, several interviewees proposed a prohibition against transgenic tests near California rice seed production sites.
An additional gap in oversight is due to an exemption for UC researchers. The CRCA states that it "shall not apply to research conducted by the University of California except for rice produced directly from the research that enters the channels of trade" (AB2622 2000). While the industry works closely with researchers to follow proper protocols (T. Johnson, California Rice Commission, personal communication, 2006) not all growers are convinced that this adequately mitigates risk (RPC 2006).

\section{Managing risks to rice marketing}

Food safety concerns such as BSE (bovine spongiform encephalopathy, or mad cow disease), E. coli and Salmonella have led buyers to implement testing requirements and even reject food shipments (O’Neill 2005). Unapproved transgenic crops receive similar scrutiny. To manage the economic risks from transgenic rice, the CRCA requires strict identity preservation for any crop that might affect the marketability of rice. While deemed a model policy, the extent to which other commodities might adopt similar policies is limited because of three unique circumstances surrounding California rice.

\section{On the LibertyLink incident}

"Any rational person would probably say, yeah, those protocols probably didn't work. I think there is an even-keeled, good case to be made that we have a good example that didn't work, and we need to look at that."

$$
\text { - Rice grower }
$$

\section{On containment}

"No one is going to control the birds . . . there is nothing we can do unless we eliminate the plot."

$$
\text { - Rice grower }
$$

\section{On export market risks}

"We have a policy in place that speaks very clearly to the fact that GE [genetically engineered] rice should not be planted until such time as there is commercial acceptance."

$$
\text { - Rice industry representative }
$$


First, the California rice industry recognized the economic risks of transgenic rice contamination, prompting preemptive legislation to ensure that the problem could be managed. Second, the rice supply chain is amenable to identity preservation because the industry already separates rice based on grain type and color. Third, the reproductive biology of rice makes identity preservation more feasible. For crops that pose greater geneflow risks, or that have more homogenous supply chains and distribution channels, similar policies are less feasible. For example, corn plants shed significant amounts of pollen to produce kernels, and much of the corn supply is delivered to elevators with homogenous supplies of corn from various sources. Identity preservation requirements are also unlikely in commodities facing little opposition to transgenic crops, such as cotton.

Herbicide-tolerant rice may be beneficial for California rice growers. But predictions of the economic benefits from transgenic rice must be considered alongside market risks. Rice shipments testing positive for transgenic traits could be rejected, likely with long-lasting repercussions. California growers could consequently face severe oversupply, lower prices and possibly decreased production (Childs and Burden 2000), underscoring the importance of a precautionary approach to market risks.

In the meantime, alternative weedmanagement options include breeding for weed-suppressive crop traits (Gibson et al. 2003); alternative tillage and stand establishment methods to pregerminate and then control weeds (Linquist et al. 2007); and long-term strategies aimed at shifting weed communities to make broad-spectrum herbicides more effective (Fischer 2004). Until transgenic rice gains market acceptance, these management strategies are likely to be less risky options for California growers.

\section{D.R. Mulvaney is Postdoctoral Scholar, Depart-} ment of Environmental Science, Policy and Management, UC Berkeley; T.J. Krupnik is Cropping Systems Agronomist, International Wheat and Maize Improvement Center, Bangladesh; and K.B. Koffler is Ph.D. Candidate, Department of Plant Sciences, UC Davis.

We wish to acknowledge four anonymous reviewers, the editors of California Agriculture, Anna Zivian and the UC Santa Cruz Agrifood group. The Robert and Patricia Switzer Foundation and UC President's Fellowship contributed partial funding.

\section{References}

AB2622. 2000. The California Rice Certification Act. www. leginfo.ca.gov/pub/99-00/bill/asm/ab 2601-2650/ ab_2622_bill_20000923_chaptered.pdf (accessed Aug. 16, 2004).

Annou MM, Wailes E, Cramer G. 2000. Economic Analysis of Adopting Liberty Link Rice. Rice Situation and Outlook. RCS-2000. USDA Economic Research Service. Washington, DC.

Bond CA, Carter CA, Farzin YH. 2003. Medium grains, high stakes: Economics of genetically modified rice in California. AgBioForum 6(4):146-54.

Bond CA, Carter CA, Farzin YH. 2005. Economic and Environmental Impacts of Adoption of Genetically Modified Rice in California. UC Giannini Foundation of Agricultural Economics. Gianinni Found Res Rep 350. Berkeley, CA.

Brookes G. 2008. Economic Impacts of Low Level Presence of Not Yet Approved GMOs on the EU Food Sector. Briefing Document, GBC Ltd. www.agrodigital.com/ images/estudio.pdf

Childs N, Burden A. 2000. The US Rice Export Market. USDA Economic Research Service. Washington, DC. www.ers.usda.gov/briefing/rice/specialarticle/ usricemarket.pdf.

Cole N. 2006. Rice farmers biggest losers over altered rice, exec says. Arkansas Democrat Gazette. www.nwanews. com/adg/News/171621 (accessed Nov. 16, 2006).

[CRC] California Rice Commission. 2010. GMO certification letter. http://calrice.thewebhounds.com/pdf/2010GMO-Cert-Letter.pdf (accessed March 15, 2010).

Cronin Fisk M, Whittington J. 2010. Bayer loses 5th straight trial over US rice crops. Bloomberg News. www. bloomberg.com (accessed Dec. 5, 2010).

Cummings B. 2009. Rice trade issues for new US trade representative Kirk. Delta Farm Press. http:// deltafarmpress.com/rice/rice-trade-issues-new-ustr-kirk. Ellstrand NC. 2006. When crop transgenes wander in California, should we worry? Cal Ag 60(3):116-25

[ERS] Economic Research Service. 2010. Adoption of Genetically Engineered Crops in the U.S. US Department of Agriculture. Washington, DC. http://www.ers.usda.gov/ Data/BiotechCrops (accessed Nov. 1, 2010).
[FDA] US Food and Drug Administration. 2006. Statement on Report of Bioengineered Rice in the Food Supply. Washington, DC. http://www.fda.gov/Food/ Biotechnology/Announcements/ucm109411.htm (accessed Feb. 6, 2011).

Fischer AJ. 2004. Comprehensive Rice Research 2004 Annual Report - Weed Control in Rice. Rice Experiment Station, Biggs, CA

Fukuda H. 2002. Japan Grain and Feed Annual Report. USDA Foreign Agriculture Service. Washington, DC.

Fukuda H, Dyck J, Stout J. 2003. Rice Sector Policies in Japan. Electronic Outlook Report. US Department of Agriculture, Economic Research Service. RCS-0303-01. Washington, DC.

[GAO] Governmental Accounting Office. 2008. Genetically Engineered Crops. A Report to the Committee on Agriculture, Nutrition, and Forestry, US Senate. GAO 0960. Washington, DC

Gibson KD, Fischer AJ, Foin TC, et al. 2003. Crop traits related to weed suppression in water-seeded rice. Weed Sci 51(1):87-93.

GMO Contamination Register. 2010. www. gmcontaminationregister.org (accessed Nov. 28, 2010) Goldberg G. 2000. Corn growers question need to sacrifice export markets due to GM crops. American Corn Growers Association. Washington, DC. www.biotech-info. net/acga_PR_3.html.

[ISB] Information Systems for Biotechnology. 2009. USDA Field Tests of GM Crops Database. www.isb.vt.edu (accessed May 6, 2009).

James C. 2009. China approves biotech rice and maize in landmark decision. International Service for the Acquisition of Agri-biotech Applications. Crop Biotech Update (Dec. 4, 2009). www.isaaa.org/kc/cropbiotechupdate/ article/default.asp?ID=5112 (accessed Oct. 1, 2010)

Li Y, Wailes E, McKenzie A, Thomsen A. 2010. LL601 contamination and its impact on US rice prices. J Ag Applied Econ 42(1):31-8.

Linquist BA, Fischer A, Godfrey L, et al. 2007. Minimum tillage could benefit California rice farmers. Cal Ag 62:24-9.

Lu B-R, Snow A. 2005. Gene flow from genetically modified rice and its environmental consequences. Bioscience 55(8):669-78.
Marvier M. 2007. Pharmaceutical crops have mixed outlook in California. Cal Ag 61(2):59-66.

Moschini GC. 2006. Pharmaceutical and industrial traits in GM crops: Coexistence with conventional agriculture. Am J Ag Econ 88(5):1184-92.

O'Neill K. 2005. U.S. beef industry faces new policies and testing for mad cow disease. Cal Ag 59(4):203-11.

[RPC] Rice Producers of California. 2006. Biotechnology Position Statement. calriceproducers.org/html/biotech position.html (accessed Nov. 15, 2006).

Salganik MJ, Heckathorn DD. 2004. Sampling and estimation in hidden populations using respondent-driven sampling. Sociolog Method 34(1):193-240.

Schultz B. 2006. LibertyLink 601 found in LSU foundation seed. Delta Farm Press. http://deltafarmpress.com (accessed Feb. 6, 2011).

Serapio M. 2010. After China, Philippines may approve GMO rice Reuters. March 16. www reuters.com/article/ idUSTRE62F0T720100316 (accessed Nov. 28, 2010).

Song ZP, Lu B-R, Zhu YG, Chen JK. 2003. Gene flow from cultivated rice to the wild species under experimenta field conditions. New Phytolog 15(7):657-65.

Sundstrom FJ, Williams J, Van Deynze A, Bradford KJ. 2002. dentity Preservation of Agricultural Commodities. UC Davis Seed Biotech Center Pub 8077. Davis, CA

Taylor MR, Tick JS, Sherman DM. 2004. Tending the Fields: State and Federal Roles in the Oversight of Genetically Modified Crops. Pew Initiative on Food and Biotechnology. December. Washington, DC.

[UCCE] UC Cooperative Extension. 2001. Rice Project Survey Results. www.agronomy.ucdavis.edu/uccerice/ NEWS/survey.htm (accessed Feb. 23, 2008).

[UCS] Union of Concerned Scientists. 2006. UCS uncovers lax USDA oversight of pharma crops. Washington, DC www.ucsusa.org/food_and_environment

Ueji M, Inao K. 2001. Rice paddy field herbicides and their effects on the environment and ecosystems. Weed Biol Manage 1(1):71-9.

Vermif P. 2006. EU and Japan block unapproved GM rice. Nature Biotech 24(10):1186.

Zerbe N. 2007. Risking regulation, regulating risk: Lessons from the transatlantic biotech dispute. Rev Policy Res 24(5):407-23. 